\title{
GLACIER MAPPING TO CONFIRM RESULTS FROM MASS-BALANCE MEASUREMENTS
}

\author{
by
}

\author{
Nils Haakensen
}

(Norwegian Water Resources and Energy Administration (NVE), P.O.Box 5091-Mj., 0301 Oslo 3, Norway)

\section{ABSTRACT}

Annual mass-balance measurements have been made at a number of glaciers in Norway since the beginning of the 1960s. A detailed and reliable map is necessary as a base for field work and more than twenty glacier maps have been constructed photogrammetrically at scales of $1: 10000$ or 1:20000 since 1952. For some of the glaciers more than one map has been constructed and changes in glacier volume can be calculated, provided the maps have sufficient accuracy.

For the glaciers, Nigardsbreen, Hellstugubreen, and Grásubreen, two or more good maps are available and these form a good basis for comparisons and calculations of changes in volume between the years when the air photographs were taken.

Comparisons have been made for Gråsubreen between 1968 and 1984, for Hellstugubreen between 1968 and 1980, and for Nigardsbreen between 1964 and 1984 .

The calculations are made by placing a $100 \mathrm{~m}$ grid on the glacier maps and comparing the altitude for corresponding points. The changes in height are regarded as representative for the $0.01 \mathrm{~km}^{2}$ glacier areas represented by each point.

Results from the investigation have been used to check the accuracy in cumulative mass balance for corresponding periods.

Repeated air photography, at intervals of 5-10 years, can be used in the future to find the cumulative mass balance for a great number of glaciers at lower cost than "normal" mass-balance work.

\section{INTRODUCTION}

Data on hydrological influence of glacier behaviour on Norwegian rivers is a vital concern for the Norwegian Water Resources and Energy Administration (NVE). In the beginning of the $1960 \mathrm{~s}$, a programme of mass-balance investigations was started at a number of selected glaciers in various parts of the country and annual mass balance has been determined for 26 different glaciers, representing altogether 275 years of field measurements. Some of the series cover only 3-5 years, whereas six of the selected glaciers have a continuous observation period of 22 years or more.

Apart from some of the very shortest series, all measurements of glacier mass balance have been performed by NVE and the Norwegian Polar Research Institute (NPI).

In these glaciological studies, which include a complete survey of annual accumulation and ablation, it is vital to have a good glacier map. Since 1951, photogrammetric maps have been made for more than 20 Norwegian glaciers, most of them solely for the purpose of mass-balance investigations (Østrem 1986). In general, the maps were issued on the scale of $1: 10000$, with a contour interval of $10 \mathrm{~m}$.

The various series of mass-balance measurements have shown that, in general, glaciers near the coast have had a tendency to increase in volume, whereas the glaciers in more continental areas have lost a considerable amount of their mass, (Fig.1). Therefore, some of the glacier maps

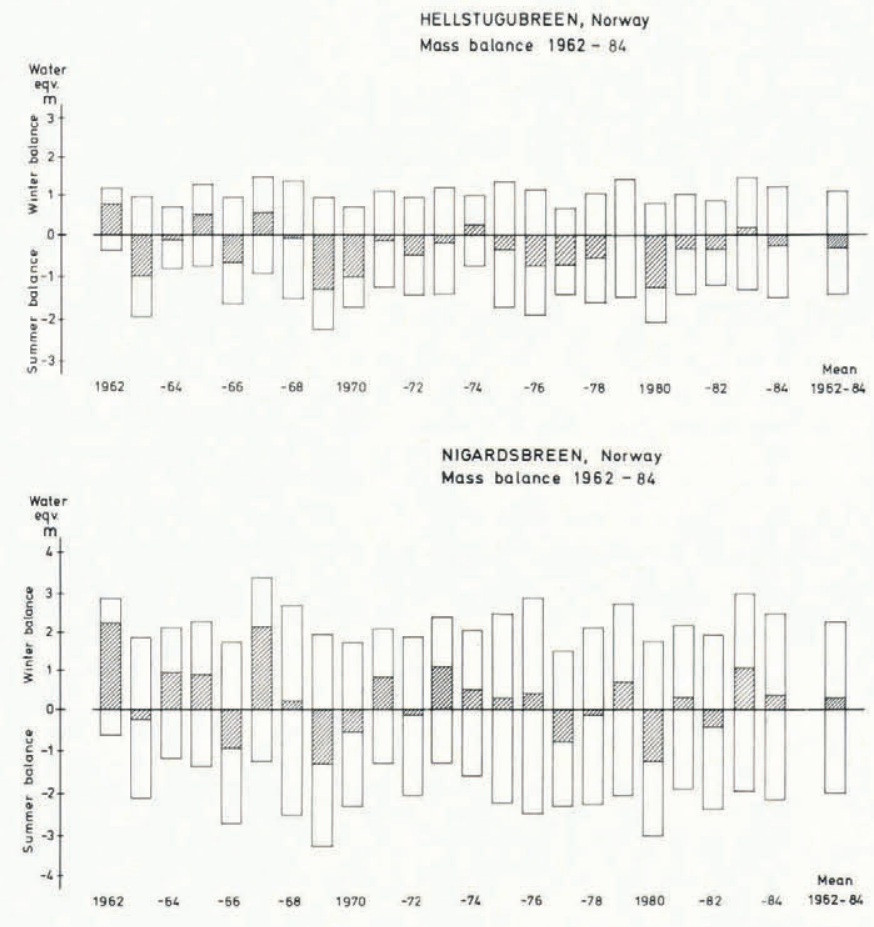

Fig.1. Winter, summer and net balance results, 1962-84, for Hellstugubreen and Nigardsbreen, determined by detailed field observations. Grásubreen shows a mass-balance pattern very similar to that of Hellstugubreen.

Hellstugubreen and Gråsubreen are continental glaciers with low mass exchange and have had a considerable net decrease during the observed period, whereas Nigardsbreen has a more maritime climate and has increased during the same period.

produced early in the investigation period had to be revised and it has been possible to use old and new maps to determine the change in glacier volume and, as a result, the average glacier mass balance could be found for the time period between the photographs. This method (the "topographic method") of determining glacier variations can be compared with the cumulative mass-balance figures obtained for the same glaciers during identical periods (the "glaciological method").

\section{EARLIER INVESTIGATIONS}

It is well known that glaciers have decreased in size during the last two hundred years. Old maps show much larger glacier areas than those present today (Fig.2). Based upon old and new topographic maps and moraine ridges 


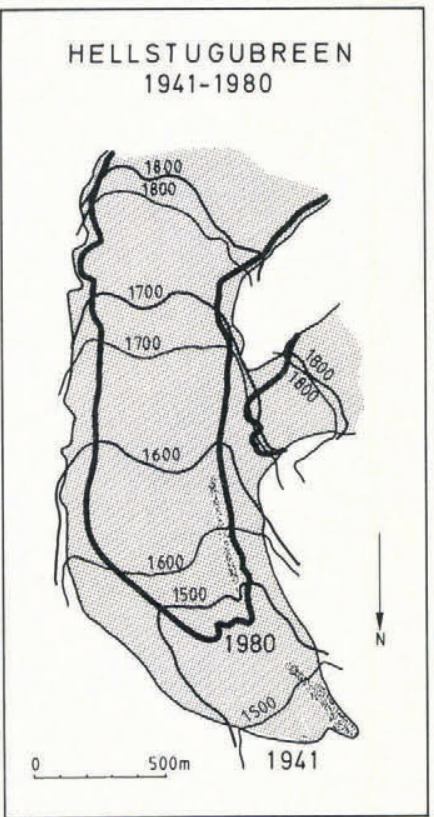

Fig.2. The map shows the retreat of Hellstugubreen during the period $1941-80$.

showing the maximum extent of glacierization (commonly supposed to have taken place in the 1750s), one can construct longitudinal profiles showing the glacier surface at specific times. Based upon such profiles, it is possible to estimate the total ice loss since 1750 . Investigations of this kind have been made for Hellstugubreen (Liestøl 1962, Fig.3), for Storbreen (Liestøl 1967) and for Nigardsbreen (Østrem et.al. 1976).

HELLSTUGUBREEN

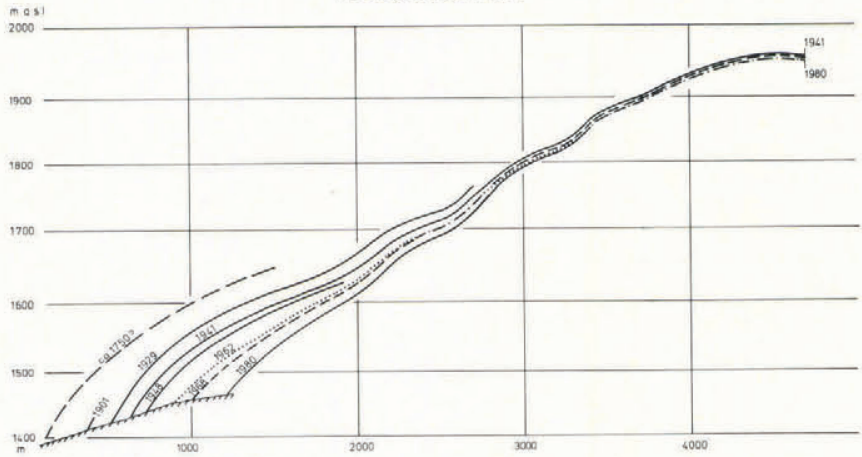

Fig.3. Longitudinal profile along the centre line of Hellstugubreen showing the height (in $\mathrm{m}$ a.s.l.) of the glacier surface at selected intervals. The maximum extent of this glacier occurred probably about 1750. This stage is reconstructed in the diagram from the outermost moraine ridges, which are clearly visible in the valley.

Finsterwalder (1954) has given a method for the determination of glacier volume change in the Alps. According to his method, two maps showing the same area are superimposed and the volume change between two contour lines, dv, is determined by the formula:

$$
\mathrm{dv}=\left(\mathrm{dF}_{1}+\mathrm{dF}_{2}\right) \cdot \frac{\Delta \mathrm{h}}{2}
$$

where

$$
\begin{aligned}
\mathrm{dF}_{1} \text { and } \mathrm{dF}_{2}= & \text { the area between corresponding contour } \\
& \text { lines on the two maps } \\
\Delta \mathrm{h} & =\text { the contour interval. }
\end{aligned}
$$

A series of special maps with $2 \mathrm{~m}$ contour interval, depicting the lower part of Tverrabbreen, in Jotunheimen was used to determine the vertical displacement of the glacier surface in the period from 1927 to 1942 (Liestøl 1962). No comparisons could be made between the "topographical" method and the "glaciological" method in this case, however, due to lack of contemporary mass-balance investigations.

Orheim (1970) constructed the hypsographic curve based on various maps of Supphellebreen, in western Norway, and determined the areas between the curves to obtain the glacier's volume changes.

\section{VOLUME CHANGE DETERMINED FROM GLACIER MAPS}

a) Background

None of the results from the above-mentioned investigations can be checked or compared with other investigations. The author has therefore studied and compared various maps, as well as data from glaciological field work on Hellstugubreen, Grảsubreen, and Nigardsbreen. For all these glaciers, there is more than one detailed glacier map available.

The object of this study was to compare changes in glacier volume, determined from map comparisons and from the cumulative mass-balance data obtained by conventional field methods. Investigations of the mass balance for these three glaciers have been very comprehensive. Both winter and summer balance have been measured with the highest possible accuracy (Haakensen 1984) and it is assumed that the annual net balance has been determined with an accuracy of $10 \mathrm{~cm}$ of water equivalent.

Most glacier maps are constructed by modern photogrammetric methods, based upon vertical air photographs taken just for the purpose of obtaining a detailed and reliable map. The negative scale of the photographs is in the range 1:20000 - 1:35000. All maps were constructed with $10 \mathrm{~m}$ contour interval and it is assumed that the relative accuracy in height determination is within $\pm 1 \mathrm{~m}$. However, some slightly larger errors can be expected where compilation was made at the very edge of a stereo model.

\section{b) Method}

For this study, a special grid consisting of $1 \mathrm{~cm}$ squares was placed over the entire glacier map so that each point represents an area of $0.01 \mathrm{~km}^{2}$. The elevation of each point was determined by a linear interpolation between the nearest two contour lines. It is assumed that the height could be determined with an accuracy of $\pm 1 \mathrm{~m}$. However, if the glacier surface is extremely steep, the distance between the contour lines is smaller and a greater uncertainty must be expected. Obviously, a condition for using this method is that the glacier surface should be relatively even between contour lines, which is the case for two of the glaciers under study, Grásubreen and Hellstugubreen, except for some points near the glacier margins, particularly in the upper part of cirques, where a larger uncertainty would appear. For Nigardsbreen, however, the ice surface on the tongue is very uneven and has many crevasses, so here the method gives less reliable data.

An identical system of points is then placed on the other map of the same glacier. Great care must be taken to ensure all points have the same location relative to bench marks in the landscape or to a given coordinate system. The height of each point in this second set must be determined by the same method as for the first map. Some errors may be expected, due to possible mis-registration, small paper deformations, or drafting generalizations. These errors are, however, assumed to be within $\pm 0.5 \mathrm{~m}$ on relatively even areas and slightly more on steep surfaces.

The arithmetic difference between the elevations for each point, determined from the two maps, is then plotted on a new map where the same grid system is used as a base. The resulting map will show differences in surface elevation for each of the points. Isolines can then be drawn through points of equal change in height, the areas between contours planimetered, and the change in volume calculated.

Another method is to multiply the height difference 
for each point by the area which it represents $\left(0.01 \mathrm{~km}^{2}\right)$. The sum represents the total volume difference.

It is obvious that good results can only be obtained when both maps are of good quality. It may be difficult to get an objective accuracy rating for the maps, but, when the two maps are placed upon each other and the contour lines for all areas outside the glacier coincide well, one may anticipate that the two map compilations are reliable. If there are large inconsistencies, it is shown below (see point b) in next section) that some corrections can be made in certain cases.

\section{RESULTS}

\section{a) Hellstugubreen}

Three glacier maps have been constructed for Hellstugubreen since the mass-balance investigations started in 1962. The first was constructed by terrestrial photogrammetry, based upon pictures taken in 1962 and the two others were constructed from vertical air photographs taken in 1968 and 1980.

The change in glacier volume has been calculated for the period 1962-68 and for the period 1968-80, according to the method described above. Comparison between the two first-mentioned maps did not give sufficiently reliable data. On the other hand, the comparison between the maps from 1968 and 1980 showed good results. On these two maps, the contour lines outside the glacier coincide very well and it is assumed that both maps depict the glacier surface with an error of less than $1 \mathrm{~m}$.

For the 12-year period, 1968-80, the glacier has decreased, particularly on the tongue. Only small changes are present in the accumulation area - small increases in height can even be found here. The figures for the surface displacement show, in general, an even decrease with height and a consistent pattern. It is, therefore, easy to draw isolines through points of equal height difference. Only in the upper parts of the glacier are there some inconsistent figures, which may be due to difficulties in map construction for these areas of relatively white and steep glacier surface. However, these areas are so small that possible errors here do not significantly influence the final result. Changes in surface elevation on Hellstugubreen from 1968 to 1980 are shown in Fig.4.

By planimetering the areas between contour lines mentioned above, we find a total reduction of glacier volume of $19.7 \times 10^{6} \mathrm{~m}^{3}$, which corresponds to a vertical reduction of $5.98 \mathrm{~m}$ averaged over the entire glacier. Using an ice density of $0.9 \mathrm{~g} / \mathrm{cm}^{3}$, this correspond to a negative mass balance of $5.39 \mathrm{~m}$ of water equivalent.

The other way of calculating, e.g. summing the displacement for each of the grid points (described above), gives almost the same result: an average lowering of the glacier surface of $6.03 \mathrm{~m}$ or a mass balance of $-5.43 \mathrm{~m}$ water equivalent.

The annual mass-balance investigations during the same period indicate a cumulative mass loss of $6.48 \mathrm{~m}$ of water equivalent, and the glacier surface area has been reduced by $10 \%$, from $3.29 \mathrm{~km}^{2}$ to $2.97 \mathrm{~km}^{2}$ (Table I).

\section{b) Grảsubreen}

Two glacier maps of this small cirque glacier are available; they are based upon vertical air photographs taken in 1968 and in $1984^{*}$, respectively.

The change in ice volume between these two occasions has been calculated in the same way as for Hellstugubreen. In this case, however, some problems arose because the contour lines on the bedrock did not coincide as well as was the case for Hellstugubreen. The height of points outside the glacier on the map from 1984 is in general $1-3 \mathrm{~m}$ higher than on the map from 1968. The difference increases from $1 \mathrm{~m}$, on the eastern side of the glacier, to $3 \mathrm{~m}$ on the western side. This consistent inaccuracy between the two maps indicates that one of the stereo models must have been slightly oblique compared to the other during the map compilations. To compensate for this inaccuracy a

* see example in map pocket on the rear cover of this volume.

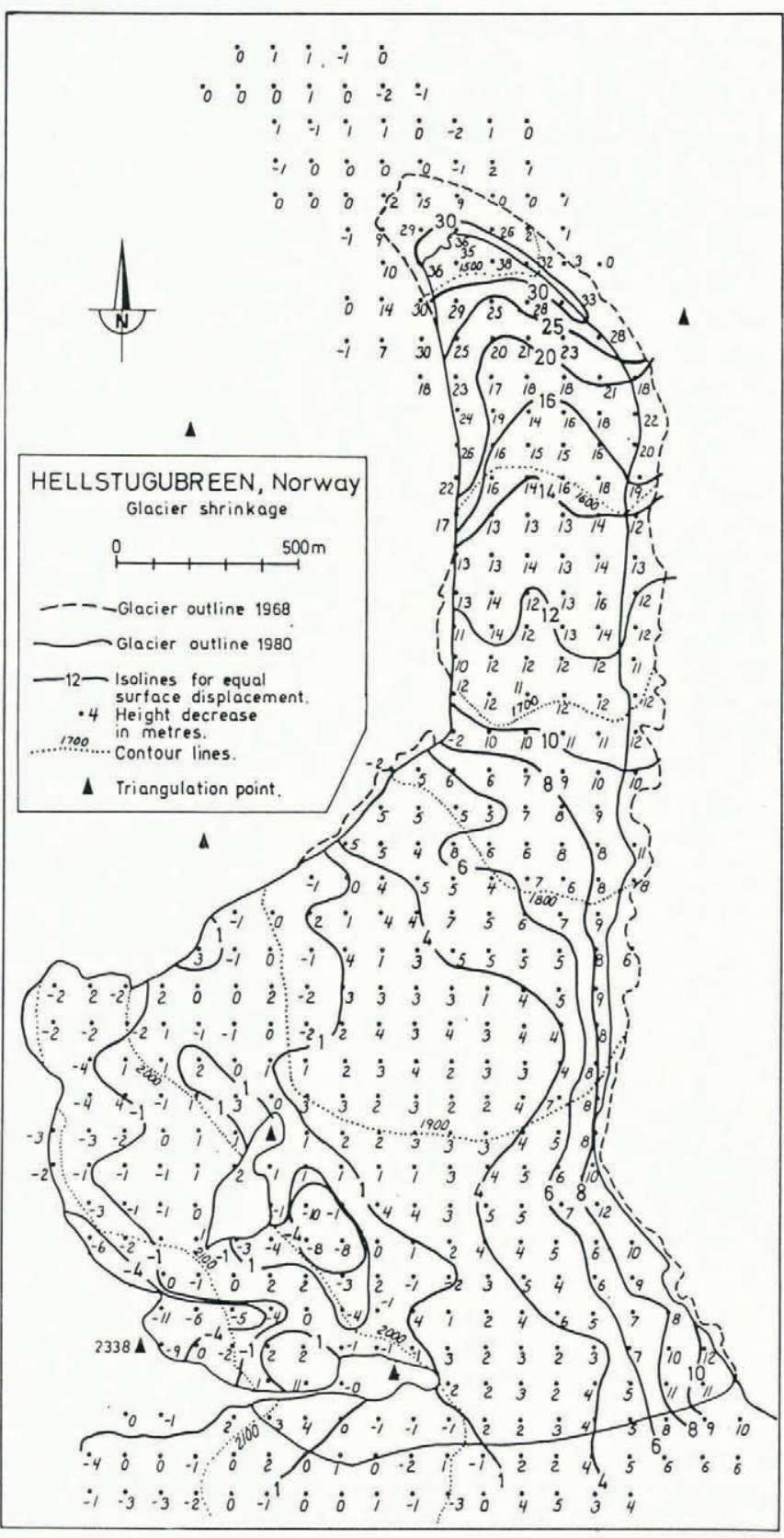

Fig.4. Glacier surface change between 1968 and 1980 at Hellstugubreen in metres, determined by map comparisons. Dots indicate the $100 \mathrm{~m}$ grid points and figures indicate the changes in height. Positive figures indicate decrease in height and negative figures indicate growth.

The pattern of figures shows a very consistent tendency below the equilibrium line (approx. $1850 \mathrm{~m}$ a.s.1.) Note that the figures outside the glacier outline from 1968 are mainly between -1 and +1 , which is a good control of the accuracy of the maps. The heavy lines are isolines drawn through points with equal height change. Dotted lines are contour lines. The glacier outline from 1968 is not drawn in places where it nearly coincides with the 1980 outline.

special reduction of all heights taken from the 1984 map was made by 1,2 and $3 \mathrm{~m}$, respectively, from east to west across the glacier. Thus, all the contour lines outside the glacier coincide much better.

The results of the measurements are shown in Fig.5. They indicate a reduction of heights, ranging from $18 \mathrm{~m}$ on the lower part of the glacier, decreasing to $0 \mathrm{~m}$ on the upper part. There are, however, slightly larger variations between adjacent points than for Hellstugubreen.

By planimetering, it was found that the glacier had lost 
Haakensen: Glacier mapping to confirm mass balance

TABLE I. TRADITIONALLY-MEASURED
HELLSTUGUBREEN AND GRÁSUBREEN COMPARED WITH CALCULATED VOLUME CHANGES DETERMINED FROM GLACIER MAPS

\begin{tabular}{lcccccc}
\hline \multicolumn{1}{c}{ Glacier } & Period & Area & $\left(\mathrm{km}^{2}\right)$ & $\mathrm{b}_{\mathrm{n}}(\mathrm{m})$ & $\mathrm{b}_{\mathrm{n}}^{\prime}(\mathrm{m})$ & $\mathrm{b}^{\prime}{ }_{\mathrm{n}}(\mathrm{m})$ \\
\hline \multirow{2}{*}{ Hellstugubreen } & $1968-80$ & 3.29 & 2.97 & -6.48 & -5.39 & -5.43 \\
Gråsubreen & $1968-84$ & 2.52 & 2.20 & -8.14 & -5.64 & -5.40 \\
\hline
\end{tabular}

$\begin{aligned} \text { Area } & =\text { glacier area measured at the two maps, old and new } \\ & =\begin{array}{l}\text { measured cumulative mass balance obtained by the } \\ \text { traditional annual field methods }\end{array} \\ \mathrm{b}^{\prime}{ }_{\mathrm{n}}, \mathrm{b}^{\prime}{ }_{\mathrm{n}} & =\begin{array}{l}\text { mass balance calculated from glacier maps, by two } \\ \text { slightly different methods, see text. }\end{array}\end{aligned}$

$15.85 \times 10^{6} \mathrm{~m}^{3}$ of ice, which corresponds to an average height reduction of $6.15 \mathrm{~m}$, or $5.64 \mathrm{~m}$ of water equivalent, during the period, 1968-84.

By using the other method, i.e. summing the values for all grid points (see above), the result will be an average loss of $5.40 \mathrm{~m}$ water equivalent (Table I).

Annual measurements of mass balance for Gråsubreen from 1968 to 1984 have shown a cumulative net balance of $-8.14 \mathrm{~m}$ water equivalent and the glacier area has been reduced during these 16 years by $13 \%$, from $2.52 \mathrm{~km}^{2}$ to $2.20 \mathrm{~km}^{2}$.

\section{c) Nigardsbreen}

Photogrammetric maps were constructed from vertical air photographs taken in 1964, 1974 and 1984. The scale of all these maps is 1:20000. Due to various problems during the air photography, a complete stereo coverage could not be obtained of certain parts of the glacier. Thus, the two first-mentioned maps had to be compiled from two different sets of air photographs taken at intervals of 9 and 8 years, respectively (Østrem 1986, Table II). Further, the air photographs taken in 1984, on which the third map compilation was based, show large areas of new snow

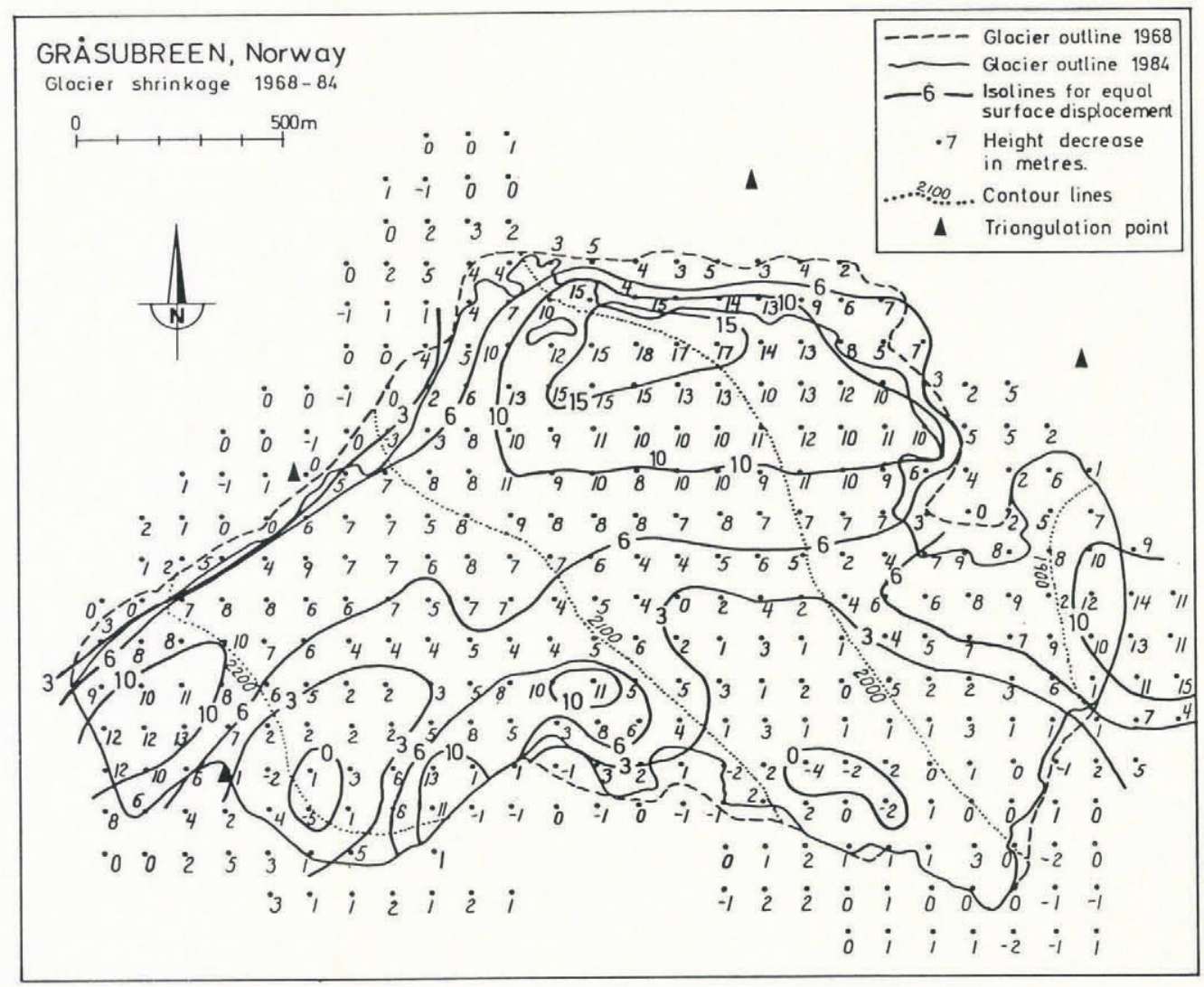

Fig.5. Glacier surface changes at Grảsubreen between 1968 and 1984, given in metres. Dots indicate the $100 \mathrm{~m}$ grid points, at which calculations were made; the figures indicate height changes. Positive figures indicate a decrease, whereas negative figures indicate glacier growth. With some few exceptions, the figures outside the glacier are between -1 and +1 , which is a control of the map accuracy. The heavy lines are isolines drawn through points of equal height change. Dotted lines are contour lines. The glacier outline from 1968 is not drawn in places where it nearly coincides with the 1984 outline. 
in the accumulation area and it proved impossible to construct reliable contour lines. The annual mass-balance investigations indicate a cumulative net balance of $3.24 \mathrm{~m}$ of water equivalent between 1964 and 1984, but it has been impossible to verify this by map comparisons.

\section{DISCUSSIONS}

The results from this study indicate that an absolute requirement of using glacier maps is that they are of a very high accuracy. Otherwise it is a doubtful task to try to determine volume changes over periods of $10-12$ years.

The statistical uncertainty, $\Delta \mathrm{h}$, connected to determination of height difference in single points, can be expressed by

$$
\Delta \mathrm{h}=\sqrt{(\Delta \mathrm{a})^{2}+(\Delta \mathrm{b})^{2}+(\Delta \mathrm{c})^{2}}
$$

where

$\Delta \mathrm{a}$ is the uncertainty in map compilation (location of contour lines)

$\Delta b$ is the uncertainty in height determination for single points in the grid

$\Delta c$ is the uncertainty due to paper shrinkage and drafting errors.

For the two glaciers under study the following values were found:

$$
\begin{aligned}
& \Delta \mathrm{a}=2 \mathrm{~m} \\
& \Delta \mathrm{b}=1 \mathrm{~m} \\
& \Delta \mathrm{c}=0.75 \mathrm{~m} .
\end{aligned}
$$

Consequently the maximum error in determining differences in height will be $\Delta h=2.3 \mathrm{~m}$. This error corresponds to about $2.0 \mathrm{~m}$ of water equivalent. A slightly higher figure will result if smaller scale maps are used. In addition, there might be some errors in the planimetering, but these are regarded as negligible when compared to the potential errors shown above.

When isolines are drawn, certain point values may be disregarded, e.g. figures which deviate too much from values in adjacent points. By drawing isolines this way, it is assumed that some of the above-mentioned errors will be eliminated; by summing all point values this elimination will not take place.

The results from Hellstugubreen showed only small variations in surface displacement from point to point and the two methods of calculation gave approximately the same result, 5.39 and $5.43 \mathrm{~m}$ of water equivalent. On Grảsubreen, however, the spatial variation seems to be larger and also the difference between results obtained by the two methods is larger (about 3\%), compare Table I.

The volume change for Hellstugubreen, determined by the "topographic" method compares well with the cumulative mass deficit as found by the "glaciological" method, i.e. the difference is within the above-mentioned expected maximum error. For Gråsubreen, however, the difference between these two methods is somewhat larger.

This larger difference may be explained by the fact that Grásubreen is regarded as a sub-polar glacier. It is the highest glacier in Norway and a large part of the accumulation takes place in the form of superimposed ice, which is difficult to measure by conventional field methods. It is probable that the measured winter balance and, consequently, the net balance has been too small and the difference between the results would be smaller than shown in Table I. An indication supporting this idea is the fact that the surface displacement (lowering of the glacier surface) in the period, 1968-84, shows smaller figures on the eastern part of the glacier, where annual field studies show the heaviest accumulation of superimposed ice.

As a recommendation for the future, one could wish that air photographs should be taken from lower altitudes, to obtain a larger negative scale to improve the accuracy in map compilation. Further, a greater number of field control points near the glacier surface should be established, thus promoting a higher accuracy in height determination and contour line construction. The map scale should not be less than $1: 10000$ and the contour interval $10 \mathrm{~m}$ or smaller. Particularly in areas of steep inclination of the glacier surface, or in areas of uneven topography, an extra set of intermediate contour lines could improve the accuracy.

\section{REFERENCES}

Finsterwalder R 1954 Photogrammetry and glacier research with special reference to glacier retreat in the eastern Alps. Journal of Glaciology 2(15): 306-315

Haakensen $\mathrm{N}(e d) 1984$ Glasiologiske undersøkelser i Norge 1981. Norges Vassdrags- og Elektrisitetsvesen. Vassdragsdirektoratet. Hydrologisk Avdeling. Rapport $1-84$

Hoel A, Werenskiold W 1962 Glaciers and snowfields in Norway. Norsk Polarinstitutt. Skrifter 114

Liestøl O 1962 Special investigations on Hellstugubreen and Tverråbreen. Norsk Polarinstitutt. Skrifter 114: 175-207

Liestøl O 1967 Storbreen glacier in Jotunheimen, Norway. Norsk Polarinstitutt. Skrifter 141

Orheim O 1970 Glaciological investigations of Store Supphellebre, West-Norway. Norsk Polarinstitutt. Skrifter 151

Østrem G 1986 Repeated glacier mapping for hydrological purposes: water power planning. Annals of Glaciology 8: $135-140$

Østrem G, Liestøl O, Wold B 1976 Glaciological investigations at Nigardsbreen, Norway. Norsk Geografisk Tidsskrifl 30(4): 187-209 